Supporting Information

\title{
Transformation of Tetracycline Antibiotics and Fe(II)/(III) Species Induced by Their Complexation
}

\footnotetext{
Hui Wang ${ }^{\mathrm{a}, \mathrm{b}}$, Hong Yao ${ }^{\mathrm{a}, \mathrm{c}, *}$, Peizhe Sun ${ }^{\mathrm{b}}$, Desheng $\mathrm{Li}^{\mathrm{a}, \mathrm{c}}$ and Ching-Hua Huang ${ }^{\mathrm{b}, *}$

${ }^{a}$ Department of Municipal and Environmental Engineering, Beijing Jiaotong University, Beijing 100044, Peoples Republic of China

${ }^{\mathrm{b}}$ School of Civil and Environmental Engineering, Georgia Institute of Technology, Atlanta, Georgia 30332, United States

${ }^{\mathrm{c}}$ Beijing Key Laboratory of Aqueous Typical Pollutants Control and Water Quality Safeguard, Beijing Jiaotong University, Beijing 100044, Peoples Republic of China

* Corresponding authors. Tel.: +86 1051682157 (H. Yao); +1 4048947694 (C.-H. Huang). E-mail addresses: yaohongts@163.com (H. Yao); ching-hua.huang@,ce.gatech.edu (C.-H. Huang).
}

Journal: $\quad$ Environmental Science \& Technology

Date Prepared: November 27, 2015

Text: $\quad$ Notation and S1-S5

Figures: S1-S13

References: $\quad 4$

Pages: $\quad 20$ 


\section{Notation for TTC and Fe(II) species:}

\begin{tabular}{|l|c|}
\hline TTC species (+1 charge) & $\mathrm{H}_{3} \mathrm{~L}$ \\
\hline Parent TTC (0 charge) & $\mathrm{H}_{2} \mathrm{~L}$ \\
\hline TTC species (-1 charge) & $\mathrm{HL}$ \\
\hline TTC species (-2 charge) & $\mathrm{L}$ \\
\hline Total TTC concentration (including different TTC species) & $\mathrm{TTC}_{\mathrm{T}}$ \\
\hline $\begin{array}{l}\text { Uncomplexed TTC (including different uncomplexed TTC } \\
\text { species) }\end{array}$ & $\mathrm{TTC}$ \\
\hline $\begin{array}{l}\text { Uncomplexed TTC concentration (including different } \\
\text { uncomplexed TTC species) }\end{array}$ & {$[\mathrm{TTC}]$} \\
\hline $\begin{array}{l}\text { Total Fe(II) (including complexed with organic and not } \\
\text { complexed) }\end{array}$ & $\mathrm{Fe}(\mathrm{II})_{\mathrm{T}}$ \\
\hline Uncomplexed Fe(II) & $\mathrm{Fe}(\mathrm{II})$ \\
\hline Uncomplexed Fe(II) concentration & {$[\mathrm{Fe}(\mathrm{II})]$} \\
\hline \begin{tabular}{l} 
Total Fe(II) and TTC complexes \\
\hline Fe(II)-H ${ }_{2} \mathrm{~L}$ complex
\end{tabular} & $\mathrm{Fe}(\mathrm{II})-\mathrm{TTC}$ \\
\hline Fe(II)-HL complex & $\mathrm{Fe}-\mathrm{H}_{2} \mathrm{~L}-\mathrm{HL}$ \\
\hline
\end{tabular}

\section{Text S1. Chemicals and Reagents}

Ammonium iron(II) sulfate hexahydrate $\left(\mathrm{Fe}\left(\mathrm{NH}_{4} \mathrm{SO}_{4}\right)_{2} \cdot 6 \mathrm{H}_{2} \mathrm{O}\right)$ was obtained from Acros at $99 \%$ purity. TTC, OTC, CTC, ferrozine (3-(2-pyridyl)-5,6-diphenyl-1,2,4-triazine-p,p'-disulfonic acid, monosodium salt hydrate), tert-butanol (TBA), catalase (lyophilized powder, 2,000-5,000 units/mg protein, from bovine liver) and superoxide dismutase (SOD, lyophilized powder, $\geq 3,000$ units/mg protein, from bovine erythrocytes) were obtained from Sigma at $90-99 \%$ purity. Humic acid (HA) was obtained from MP Biomedicals (Santa Ana, CA, US). All other reagents used (e.g., buffers, acids, etc.) were obtained from Fisher Scientific (Hampton, NH, US), Acros (Geel, BEL) or Aldrich (St. Louis, MO, US) at analytical grade. All chemicals were used directly without further purification. Reagent water 
was produced from a Millipore Milli-Q Ultrapure Gradient A10 purification system (Millipore, Billerica, MA, US).

TC stock solutions were prepared in reagent water at $1.6 \mathrm{mM}$, protected from light, stored at $5^{\circ} \mathrm{C}$ and used within 2-3 days. The $4.0 \mathrm{mM} \mathrm{Fe}(\mathrm{II})$ stock solutions were prepared by dissolving $\mathrm{Fe}\left(\mathrm{NH}_{4} \mathrm{SO}_{4}\right)_{2} \cdot 6 \mathrm{H}_{2} \mathrm{O}$ in $0.2 \mathrm{M} \mathrm{HCl}^{1}$, stored at $5^{\circ} \mathrm{C}$ and used within one month. $\mathrm{Fe}(\mathrm{III})$ stock solution was made by dissolving $2.0 \mathrm{mM} \mathrm{FeCl}_{3}$ at $\mathrm{pH} 2.3$ (adjusted by $\mathrm{HCl}$ ) and stored at $4^{\circ} \mathrm{C}$. The desired solution $\mathrm{pH}$ was maintained using $10 \mathrm{mM}$ buffer of 2-(N-morpholino)ethanesulfonic acid (MES) for $\mathrm{pH}$ 5.5-6.5, and 4-morpholinepropanesulfonic acid (MOPS) for $\mathrm{pH}$ 6.5-7.5.

\section{Text S2. Fe(II) determination by ferrozine (FZ)}

To measure Fe(II) concentration, typically $0.5 \mathrm{~mL}$ of sample was added into a cuvette $(1.0 \mathrm{~cm}$ path length) that contained $0.4 \mathrm{~mL}$ of ferrozine (FZ) solution. Three concentrations of FZ solution $(1,10$ and $100 \mathrm{mM})$ were tested to determine the sufficient FZ concentration for this study. It was found that when FZ concentration was increased from 1 to $100 \mathrm{mM}$ for varius samples in this study, the absorbance of the detected Fe(II) (including experiments conducted in the presence of TCs and HA) did not change. Thus, $1 \mathrm{mM} \mathrm{FZ} \mathrm{was} \mathrm{considered} \mathrm{sufficient} \mathrm{for}$ $\mathrm{Fe}(\mathrm{II})$ determination in this study. Moreover, it was found that at FZ concentration of $1 \mathrm{mM}$, all samples' initial absorbance was nearly identical regardless of varying concentrations of $\mathrm{Fe}(\mathrm{II}), \mathrm{TC}$ and/or HA, which also verified that $1 \mathrm{mM} \mathrm{FZ}$ was sufficient for $\mathrm{Fe}(\mathrm{II})$ detection in this study.

\section{Text S3. Determination of the complexation constants of Fe(II)-TTC Complexes}

Experiments to study the Fe(II)-TC complexation were conducted in anoxic conditions to minimize Fe(II)'s oxidation during the measurement. Before the complexation reaction, all the stock solutions (including the Fe(II) stock, TTC stock and buffers) were purged by high purity nitrogen for 1 hour to drive the dissolved oxygen out. The complexation experiments were conducted in 10-mL centrifuge tubes with cover. The experiments were started by adding a fixed amount of Fe(II) stock to the buffers ( $\mathrm{pH}$ 6.0, 6.5 and 7.0) containing different concentrations of TTC (varying from 10 to $160 \mu \mathrm{M}$ ). Nitrogen was purged throughout the 
complexation reaction $(<30 \mathrm{~s})$. Then, the centrifuge tubes were covered until measurement. Shortly after, aliquots were taken from the covered centrifuge tubes and transferred to cuvettes to measure UV absorbance within 30 seconds. Thus, the entire process was completed in less than $1 \mathrm{~min}$.

For 1:1 Fe(II)-TTC complex formation (eq 1), based on the Benesi-Hildebrand equation (eqn 1 ), ${ }^{2,3}$ there would be an relationship between [TTC] and $\Delta$ (Absorbance) (eq 2):

$\mathrm{Fe}(\mathrm{II})+\mathrm{TTC} \rightleftharpoons \mathrm{Fe}(\mathrm{II})-\mathrm{TTC} \quad \mathrm{K}_{1: 1}=\frac{[\mathrm{Fe}(\mathrm{II})-\mathrm{TTC}]}{[\mathrm{TTC}][\mathrm{Fe}(\mathrm{II})]}$

where $[\mathrm{Fe}(\mathrm{II})]$ and $[\mathrm{TTC}]$ are the concentrations of uncomplexed $\mathrm{Fe}(\mathrm{II})$ and TTC, respectively, and $\mathrm{K}_{1: 1}$ is the $1: 1$ complexation constant.

$\frac{1}{\Delta(\text { Absorbance })}=\frac{1}{\mathrm{Fe}(\mathrm{II})_{\mathrm{T}} \mathrm{K}_{1} \Delta \epsilon_{1}} \times \frac{1}{[\mathrm{TTC}]}+\frac{1}{\mathrm{Fe}(\mathrm{II})_{\mathrm{T}} \Delta \epsilon_{1}}$

where $\Delta$ (Absorbance) was the difference in the UV absorbance of the Fe(II)-TTC complex in comparison to the UV absorbance of the uncomplexed Fe(II) plus the UV absorbance of uncomplexed TTC; Fe(II)T was the total Fe(II) concentration; and $\Delta \epsilon_{1}=\epsilon_{1}-\epsilon_{\mathrm{Fe}(\mathrm{II})}-\epsilon_{\mathrm{TTC}}$ (the molar absorptivity of Fe(II)-TTC complex minus the absorptivities of uncomplexed Fe(II) and uncomplexed TTC). By plotting 1/[TTC] versus $1 / \Delta$ (Absorbance), the complexation constant $\mathrm{K}_{1: 1}$ could be calculated from dividing the intercept by the slope. Complexometric titration experiments were conducted at a fixed $\mathrm{Fe}(\mathrm{II})_{\mathrm{T}}(40 \mu \mathrm{M})$ with varying [TTC] $(30-160$ $\mu \mathrm{M}$ ) (Assuming $[\mathrm{TTC}] \approx[\mathrm{TTC}]_{0}$, because $[\mathrm{Fe}(\mathrm{II})-\mathrm{TTC}]<<[\mathrm{TTC}]$ ). As shown in Figure S5 as an example, the $\mathrm{K}_{1: 1}$ value was determined to be $2713.5( \pm 316.1)$ for $\mathrm{pH} 6.0,3856.0( \pm 352.0)$ for $\mathrm{pH} 6.5$ and $4974.4( \pm 448.9)$ for $\mathrm{pH} 7.0$.

The different values of $\mathrm{K}_{1: 1}$ at different $\mathrm{pHs}$ indicated that the speciation of TTC needed to be taken into account in the complexation reaction. As shown in Figure S6, TTC has four possible species: $\mathrm{H}_{3} \mathrm{~L}, \mathrm{H}_{2} \mathrm{~L}, \mathrm{HL}$ and $\mathrm{L}$ (corresponding to three acid dissociation constants). ${ }^{4}$ The different $\mathrm{K}_{1: 1}$ values at different $\mathrm{pH}$ were due to involvement of different TTC species in the complexation. In the moderate $\mathrm{pH}$ range (5.5-7.5) examined in this study, $\mathrm{H}_{2} \mathrm{~L}$ and $\mathrm{HL}$ species were dominant (eq 3). Thus, the Fe(II)-TTC complex formation could exist as $\mathrm{Fe}^{\mathrm{II}}-\mathrm{H}_{2} \mathrm{~L}$ and $\mathrm{Fe}^{\mathrm{II}}-\mathrm{HL}$ accordingly (eqs 4 and 5):

$$
\mathrm{H}_{2} \mathrm{~L} \rightleftharpoons \mathrm{HL}+\mathrm{H}^{+} \quad \mathrm{K}_{\mathrm{a}_{2}}=\frac{[\mathrm{HL}]\left[\mathrm{H}^{+}\right]}{\left[\mathrm{H}_{2} \mathrm{~L}\right]}=10^{-7.78}
$$




$$
\begin{array}{ll}
\mathrm{Fe}(\mathrm{II})+\mathrm{H}_{2} \mathrm{~L} \rightleftharpoons \mathrm{Fe}^{\mathrm{II}}-\mathrm{H}_{2} \mathrm{~L} & \mathrm{~K}_{\mathrm{Fe}^{\mathrm{II}}-\mathrm{H}_{2} \mathrm{~L}}=\frac{\left[\mathrm{Fe}^{\mathrm{II}}-\mathrm{H}_{2} \mathrm{~L}\right]}{\left[\mathrm{H}_{2} \mathrm{~L}\right][\mathrm{Fe}(\mathrm{II})]} \\
\mathrm{Fe}(\mathrm{II})+\mathrm{HL} \rightleftharpoons \mathrm{Fe}^{\mathrm{II}}-\mathrm{HL} & \mathrm{K}_{\mathrm{Fe}^{\mathrm{II}}-\mathrm{HL}}=\frac{\left[\mathrm{Fe}^{\mathrm{II}}-\mathrm{HL}\right]}{[\mathrm{HL}][\mathrm{Fe}(\mathrm{II})]}
\end{array}
$$

Therefore, $\mathrm{K}_{1: 1}$ represented the overall complexation formation constant for both $\mathrm{Fe}^{\mathrm{II}}-\mathrm{H}_{2} \mathrm{~L}$ and $\mathrm{Fe}^{\mathrm{II}}$-HL species (eq 6):

$\mathrm{K}_{1: 1}=\frac{[\mathrm{Fe}(\mathrm{II})-\mathrm{TTC}]}{[\mathrm{TTC}][\mathrm{Fe}(\mathrm{II})]}=\frac{\left[\mathrm{Fe}^{\mathrm{II}}-\mathrm{H}_{2} \mathrm{~L}\right]+\left[\mathrm{Fe}^{\mathrm{II}}-\mathrm{HL}\right]}{\left(\left[\mathrm{H}_{2} \mathrm{~L}\right]+[\mathrm{HL}]\right)[\mathrm{Fe}(\mathrm{II})]}$

Based on eqs 3-5, eq 6 could be rewritten as eq 7:

$$
\mathrm{K}_{1: 1}=\frac{\left[\mathrm{Fe}^{\mathrm{II}}-\mathrm{H}_{2} \mathrm{~L}\right]+\left[\mathrm{Fe}^{\mathrm{II}}-\mathrm{HL}\right]}{\left(\left[\mathrm{H}_{2} \mathrm{~L}\right]+[\mathrm{HL}]\right)[\mathrm{Fe}(\mathrm{II})]}=\frac{\mathrm{K}_{\mathrm{Fe}^{\mathrm{II}}-\mathrm{H}_{2} \mathrm{~L}}[\mathrm{Fe}(\mathrm{II})]+\frac{\mathrm{K}_{\mathrm{Fe}^{\mathrm{II}}-\mathrm{HL}}[\mathrm{Fe}(\mathrm{II})] \mathrm{K}_{a 2}}{\left[\mathrm{H}^{+}\right]}}{\left(1+\frac{\mathrm{K}_{a 2}}{\left[\mathrm{H}^{+}\right]}\right)[\mathrm{Fe}(\mathrm{II})]}=\frac{\mathrm{K}_{\mathrm{Fe}^{\mathrm{II}}-\mathrm{H}_{2} \mathrm{~L}}\left[\mathrm{H}^{+}\right]+\mathrm{K}_{\mathrm{Fe}^{\mathrm{II}}-\mathrm{HL}} \cdot \mathrm{K}_{a 2}}{\left[\mathrm{H}^{+}\right]+\mathrm{K}_{a 2}}
$$

Based on the measured $\mathrm{K}_{1: 1}$ values at $\mathrm{pH} 6.0,6.5$ and 7.0, the eq 7 was solved for $\mathrm{K}_{\mathrm{Fe}^{\mathrm{II}}-\mathrm{H}_{2} \mathrm{~L}}$ and $\mathrm{K}_{\mathrm{Fe}^{\mathrm{II}}-\mathrm{HL}}$ using Matlab to be $\mathbf{2 . 3 9} \times \mathbf{1 0}^{\mathbf{3}}$ and $\mathbf{2 . 0 5} \times \mathbf{1 0}^{4}$, respectively.

Furthermore, the obtained complexation constants of $\mathrm{Fe}^{\mathrm{II}}-\mathrm{H}_{2} \mathrm{~L}$ and $\mathrm{Fe}^{\mathrm{II}}-\mathrm{HL}$ were used to calculate the speciation of $\mathrm{Fe}(\mathrm{II})(40 \mu \mathrm{M})$ in the presence of different amounts of TTC at $\mathrm{pH}$ 6.5 and 7.0, respectively, on the basis of the mass balances of total Fe(II) and total TTC (eqs 8 and 9).

$$
\begin{aligned}
& \mathrm{Fe}(\mathrm{II})_{\mathrm{T}}=[\mathrm{Fe}(\mathrm{II})]+\left[\mathrm{Fe}^{\mathrm{II}}-\mathrm{H}_{2} \mathrm{~L}\right]+\left[\mathrm{Fe}^{\mathrm{II}}-\mathrm{HL}\right] \\
& =[\mathrm{Fe}(\mathrm{II})]\left(1+\frac{\mathrm{K}_{\mathrm{Fe}^{\mathrm{II}}-\mathrm{H}_{2} \mathrm{~L}}}{\mathrm{~K}_{a 2}}\left[\mathrm{H}^{+}\right][\mathrm{HL}]+\mathrm{K}_{\mathrm{Fe}^{\mathrm{II}}-\mathrm{HL}}[\mathrm{HL}]\right) \\
& \mathrm{TTC}_{\mathrm{T}}=\left[\mathrm{H}_{2} \mathrm{~L}\right]+[\mathrm{HL}]+\left[\mathrm{Fe}^{\mathrm{II}}-\mathrm{H}_{2} \mathrm{~L}\right]+\left[\mathrm{Fe}^{\mathrm{II}}-\mathrm{HL}\right]
\end{aligned}
$$

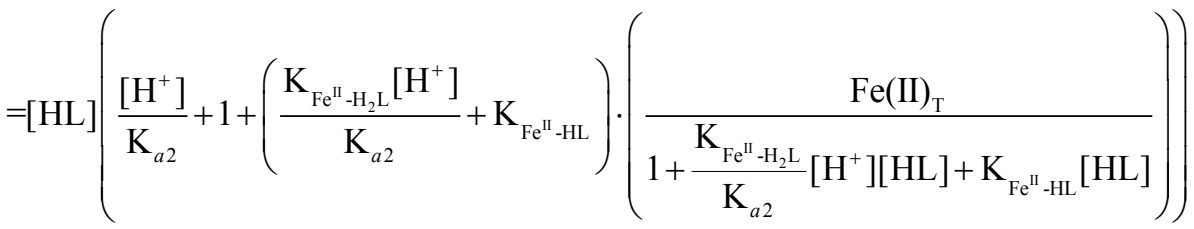

As shown in Figure S7, at pH 6.5 for example, the percentage of Fe(II) complexed with TTC increased from $11 \%$ to $38 \%$ when TTC $_{\mathrm{T}}$ increased from $40 \mu \mathrm{M}$ to $200 \mu \mathrm{M}$.

\section{Text S4. Determination of Oxidation Rate Constant of Fe(II)-TTC Complex}

As described in the main text, the autoxidation rate constant of Fe(II) in the presence of both $\mathrm{Fe}(\mathrm{II})$ and TTC could be expressed as: 
$k_{\text {obs }}\left(\mathrm{Fe}(\mathrm{II})_{\mathrm{T}}\right)=k_{i}[\mathrm{Fe}(\mathrm{II})]+k_{\mathrm{Fe}^{\mathrm{II}}-\mathrm{H}_{2} \mathrm{~L}}\left[\mathrm{Fe}^{\mathrm{II}}-\mathrm{H}_{2} \mathrm{~L}\right]+k_{\mathrm{Fe}^{\mathrm{II}}-\mathrm{HL}}\left[\mathrm{Fe}^{\mathrm{II}}-\mathrm{HL}\right]$

By combining with eqs 3-5 and the mass balance of total Fe(II) (eq 8), eq 10 could be expressed as eq 11 .

$$
\begin{aligned}
k_{\text {obs }}= & \frac{k_{i}[\mathrm{Fe}(\mathrm{II})]+k_{\mathrm{Fe}^{\mathrm{II}}-\mathrm{H}_{2} \mathrm{~L}}\left[\mathrm{Fe}^{\mathrm{II}}-\mathrm{H}_{2} \mathrm{~L}\right]+k_{\mathrm{Fe}^{\mathrm{II}}-\mathrm{HL}}\left[\mathrm{Fe}^{\mathrm{II}}-\mathrm{HL}\right]}{[\mathrm{Fe}(\mathrm{II})]+\left[\mathrm{Fe}^{\mathrm{II}}-\mathrm{H}_{2} \mathrm{~L}\right]+\left[\mathrm{Fe}^{\mathrm{II}}-\mathrm{HL}\right]} \\
= & \frac{k_{i}+k_{\mathrm{Fe}^{\mathrm{II}}-\mathrm{H}_{2} \mathrm{~L}} \mathrm{~K}_{\mathrm{Fe}^{\mathrm{II}}-\mathrm{H}_{2} \mathrm{~L}}\left[\mathrm{H}_{2} \mathrm{~L}\right]+k_{\mathrm{Fe}^{\mathrm{II}}-\mathrm{HL}} \mathrm{K}_{\mathrm{Fe}^{\mathrm{II}}-\mathrm{HL}}[\mathrm{HL}]}{1+\mathrm{K}_{\mathrm{Fe}^{\mathrm{II}}-\mathrm{H}_{2} \mathrm{~L}}\left[\mathrm{H}_{2} \mathrm{~L}\right]+\mathrm{K}_{\mathrm{Fe}^{\mathrm{II}} \mathrm{-HL}}[\mathrm{HL}]} \\
= & \frac{k_{i}+k_{\mathrm{Fe}^{\mathrm{II}}-\mathrm{H}_{2} \mathrm{~L}} \mathrm{~K}_{\mathrm{Fe}^{\mathrm{II}}-\mathrm{H}_{2} \mathrm{~L}} \frac{\left[\mathrm{H}^{+}\right]}{\mathrm{K}_{a 2}}[\mathrm{HL}]+k_{\mathrm{Fe}^{\mathrm{II}}-\mathrm{HL}} \mathrm{K}_{\mathrm{Fe}^{\mathrm{II}}-\mathrm{HL}}[\mathrm{HL}]}{1+\frac{\mathrm{K}_{\mathrm{Fe}^{\mathrm{II}}-\mathrm{H}_{2} \mathrm{~L}}}{\mathrm{~K}_{a 2}}\left[\mathrm{H}^{+}\right][\mathrm{HL}]+\mathrm{K}_{\mathrm{Fe}^{\mathrm{II}} \mathrm{HL}}[\mathrm{HL}]}
\end{aligned}
$$

The $k_{o b s}$ was measured at a fixed initial $[\mathrm{Fe}(\mathrm{II})]_{\mathrm{T}}(40 \mu \mathrm{M})$ but with varying initial $[\mathrm{TTC}]_{\mathrm{T}}$ $(0-200 \mu \mathrm{M})$ at $\mathrm{pH} 6.5$ and 7.0, respectively. The eqs 9 and 11 were solved simultaneously with respect to the experimental data of $k_{\mathrm{obs}}$ for the unknown $k_{\mathrm{Fe}^{\mathrm{II}}-\mathrm{H}_{2} \mathrm{~L}}$ and $k_{\mathrm{Fe}^{\mathrm{II}}-\mathrm{HL}}$ using Matlab. The $k_{\mathrm{Fe}^{\mathrm{II}}-\mathrm{H}_{2} \mathrm{~L}}$ and $k_{\mathrm{Fe}^{\mathrm{II}}-\mathrm{HL}}$ were calculated to be $\mathbf{0 . 2 6 9} \mathbf{m i n}^{-\mathbf{1}}$ and $\mathbf{1 . 5 1 1} \mathbf{m i n}^{\mathbf{- 1}}$, respectively.

\section{Text S5. TTC's degradation in the presence of $\mathrm{Fe}(\mathrm{III})$ and $\mathrm{H}_{2} \mathrm{O}_{2}$}

In order to test the hypothesis that $\mathrm{H}_{2} \mathrm{O}_{2}$ complexes with $\mathrm{Fe}(\mathrm{III})-\mathrm{TTC}$ and further oxidizes TTC (described by the two reactions below), experiments were conducted in a solution containing $40 \mu \mathrm{M}$ TTC, $40 \mu \mathrm{M}$ Fe(III), $0.1 \mathrm{M}$ TBA and $3 \mu \mathrm{M} \mathrm{H}_{2} \mathrm{O}_{2}$ at pH 6.5 (buffered by 10 mM MOPS). The concentration of Fe(III) was chosen because at most $40 \mu \mathrm{M} \mathrm{Fe}(\mathrm{III})$ could be produced within the reaction time. Although accurate $\mathrm{H}_{2} \mathrm{O}_{2}$ concentration was difficult to estimate, $3 \mu \mathrm{M} \mathrm{H}_{2} \mathrm{O}_{2}$ was expected to be higher than that in the system containing $40 \mu \mathrm{M}$ TTC and $40 \mu \mathrm{M}$ Fe(II). TBA was added into the solution to scavenge ROS produced by the reaction between $\mathrm{Fe}(\mathrm{III})$ and $\mathrm{H}_{2} \mathrm{O}_{2}$. Results showed that less than $5 \%$ of total TTC was degraded in the $\mathrm{H}_{2} \mathrm{O}_{2}-\mathrm{Fe}(\mathrm{III})-\mathrm{TTC}$ system within 90 min. Therefore, the degradation of TTC via the $\mathrm{H}_{2} \mathrm{O}_{2}-\mathrm{TTC}-\mathrm{Fe}(\mathrm{III})$ complex was negligible.

$\mathrm{Fe}(\mathrm{III})-\mathrm{TTC}+\mathrm{H}_{2} \mathrm{O}_{2}=\mathrm{H}_{2} \mathrm{O}_{2}-\mathrm{Fe}(\mathrm{III})-\mathrm{TTC}$

$\mathrm{H}_{2} \mathrm{O}_{2}-\mathrm{Fe}(\mathrm{III})-\mathrm{TTC}=\mathrm{Fe}(\mathrm{III})+\mathrm{TTCox}+2 \mathrm{OH}^{-}$ 

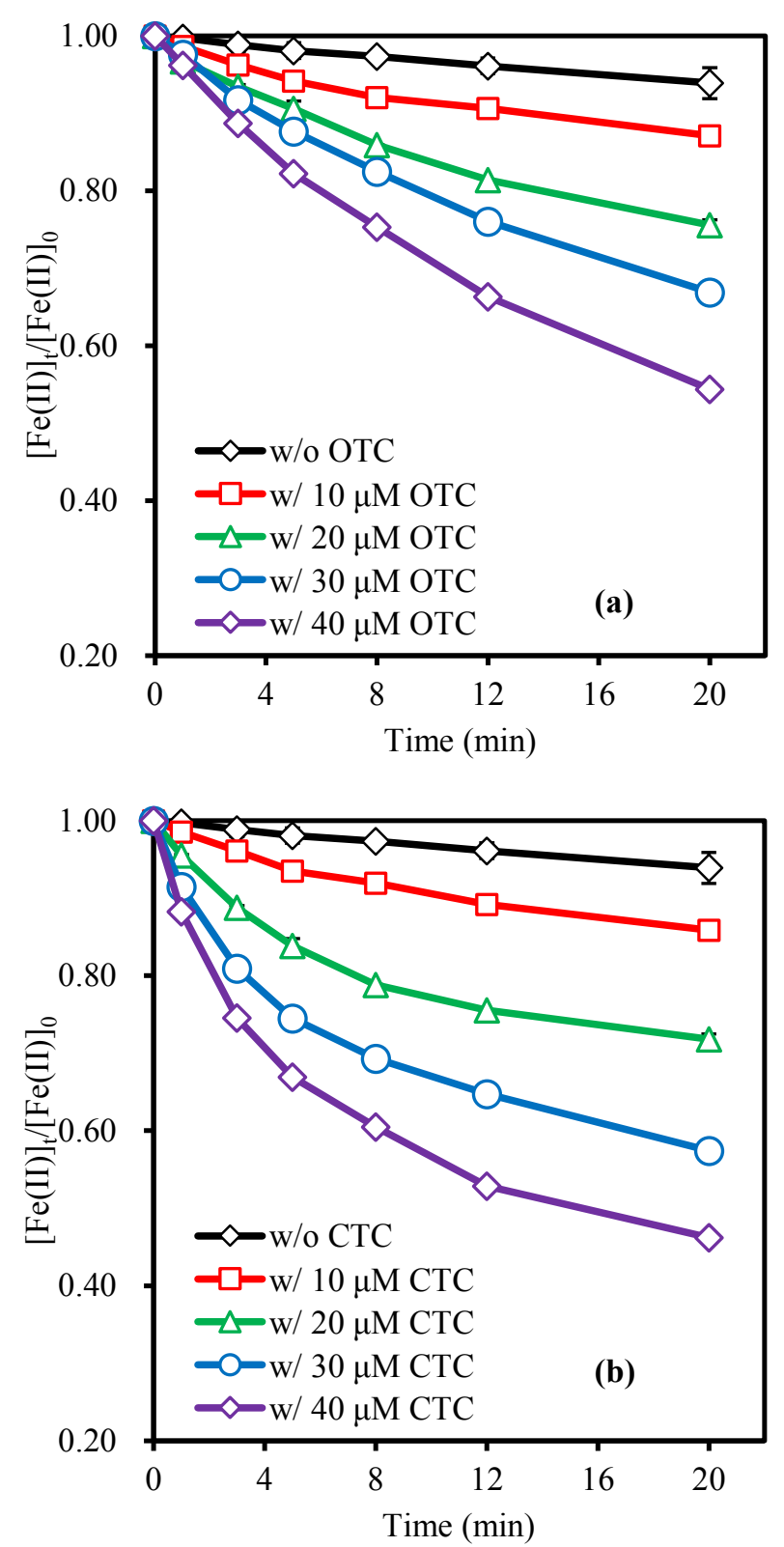

Figure S1. Oxidation of Fe(II) at different initial OTC (a) and CTC (b) concentrations in 20 min. Conditions: $[\mathrm{Fe}(\mathrm{II})]_{0}=40 \mu \mathrm{M}, \mathrm{pH}=6.5$ (buffered by $10 \mathrm{mM}$ MOPS), $\mathrm{T}=22{ }^{\circ} \mathrm{C}$, with air purging. 


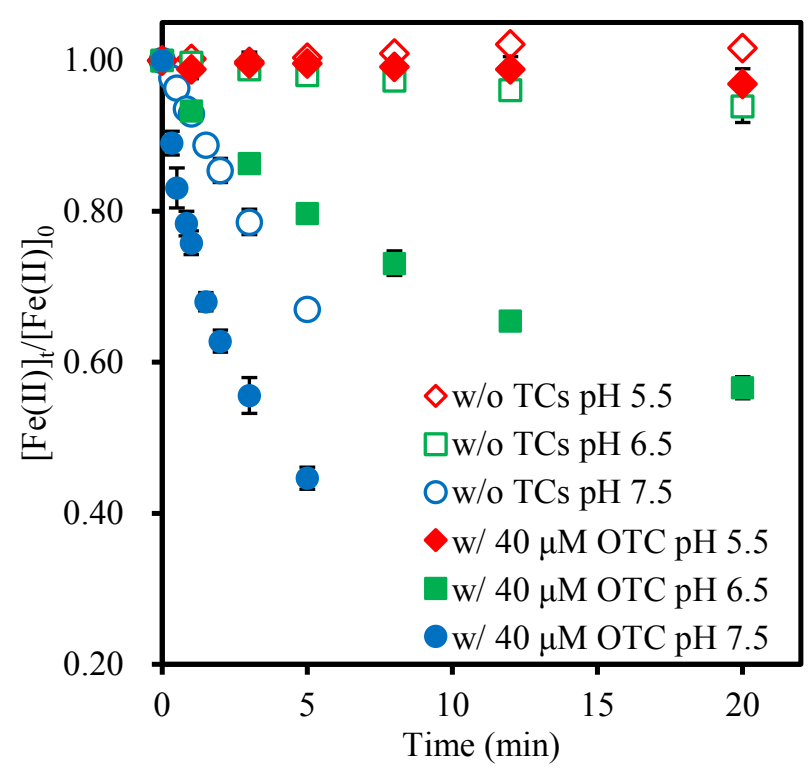

Figure S2. Fe(II)'s oxidation in the absence and presence of OTC at different $\mathrm{pH}$. Conditions: $[\mathrm{Fe}(\mathrm{II})]_{0}=40 \mu \mathrm{M}$, buffered by $10 \mathrm{mM}$ MES for $\mathrm{pH} 5.5$ and $10 \mathrm{mM}$ MOPS for $\mathrm{pH} 6.5$ and 7.5 , $\mathrm{T}=22{ }^{\circ} \mathrm{C}$, with air purging. 

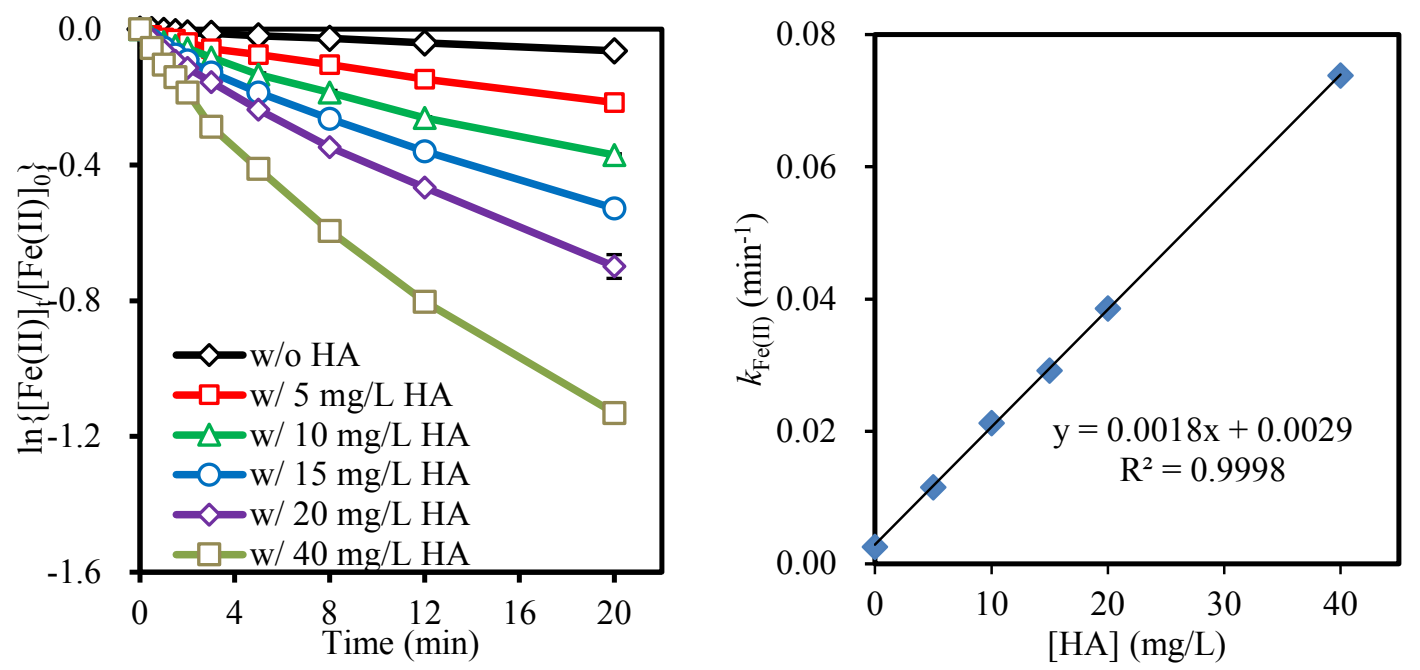

Figure S3. HA's effect on the oxidation of Fe(II). Conditions: $[\mathrm{Fe}(\mathrm{II})]_{0}=40 \mu \mathrm{M}, \mathrm{pH}=6.5$ (buffered by $10 \mathrm{mM}$ MOPS), $\mathrm{T}=22^{\circ} \mathrm{C}$, with air purging. 

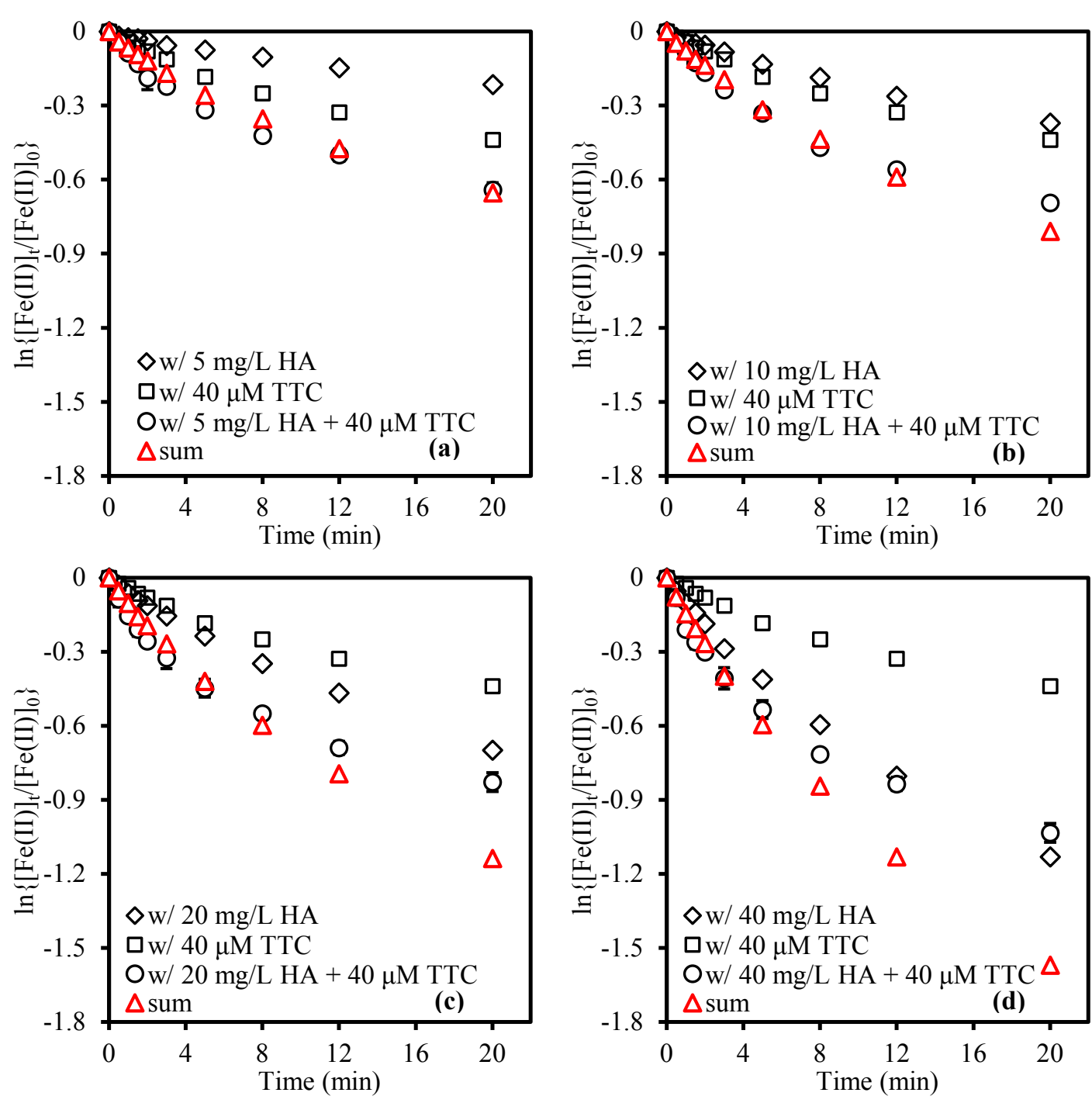

Figure S4. Oxidation of Fe(II) in the presence of TTC and HA. Condition: $[\mathrm{Fe}(\mathrm{II})]_{0}=[\mathrm{TTC}]_{0}$ $=40 \mu \mathrm{M},[\mathrm{HA}]_{0}=5,10,20$ and $40 \mathrm{mg} / \mathrm{L}, \mathrm{pH}=6.5$ (buffered by $10 \mathrm{mM}$ MOPS), $\mathrm{T}=22{ }^{\circ} \mathrm{C}$, with air purging. Sum $=$ the mathematic sum of the effect of HA only and the effect of 40 $\square \mathrm{M}$ TTC only. 

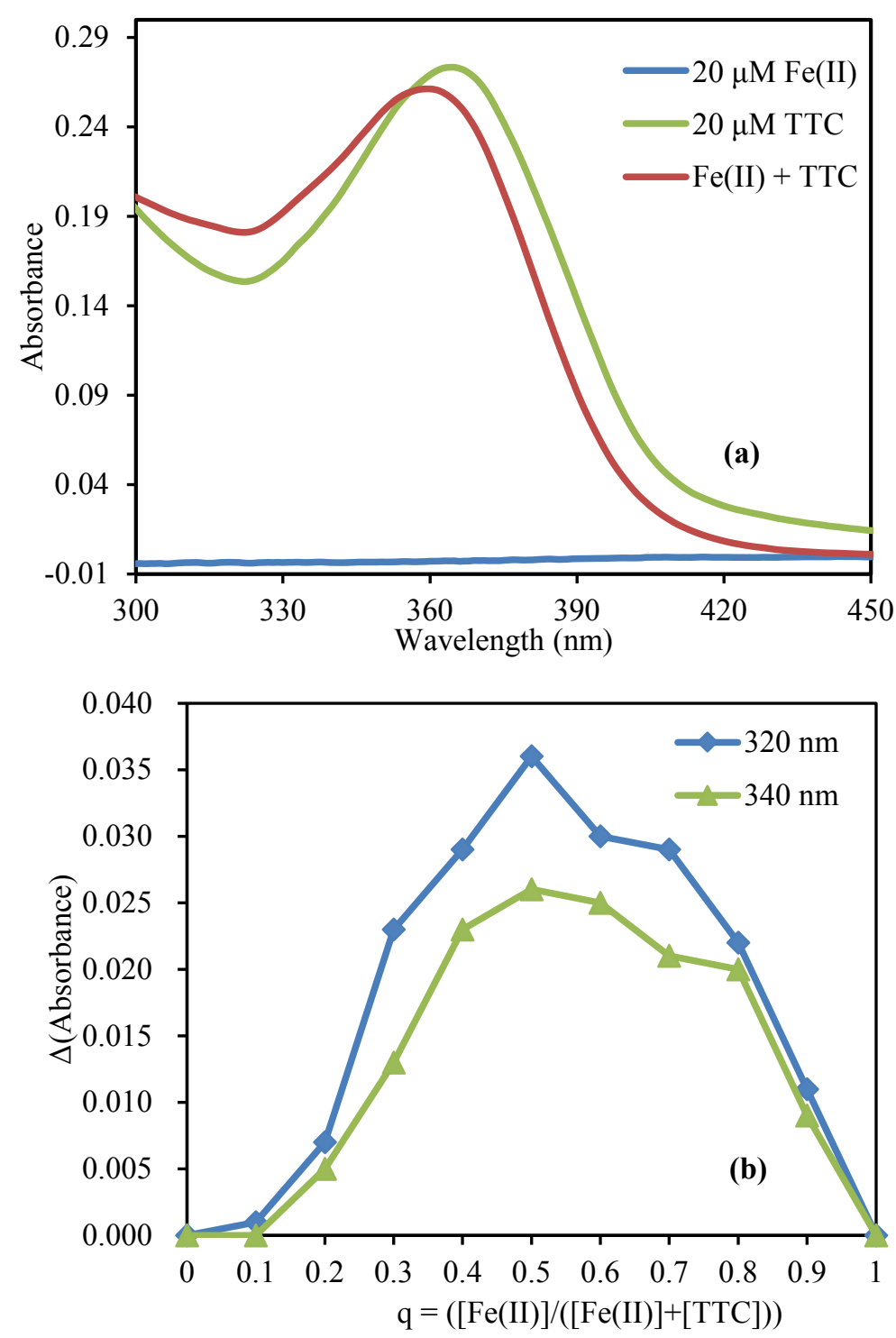

Figure S5. Complexation of Fe(II) and TTC: (a) UV spectra of solutions containing Fe(II) only, TTC only, and Fe(II) plus TTC, at pH 6.5; (b) Job's plot for the complexation of Fe(II) and TTC at $\mathrm{pH}$ 6.5. The total concentration of Fe(II) and TTC was held constant at $40 \mu \mathrm{M}$. 


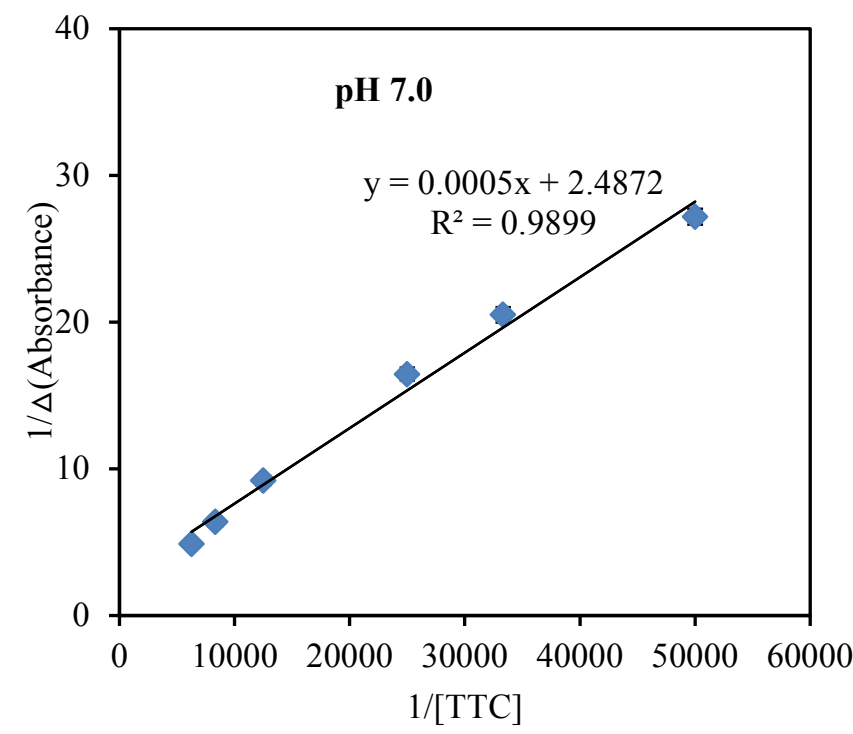

Figure S6. Linear relationship by plotting 1/[TTC] versus 1/A(Absorbance) at pH 7.0. 

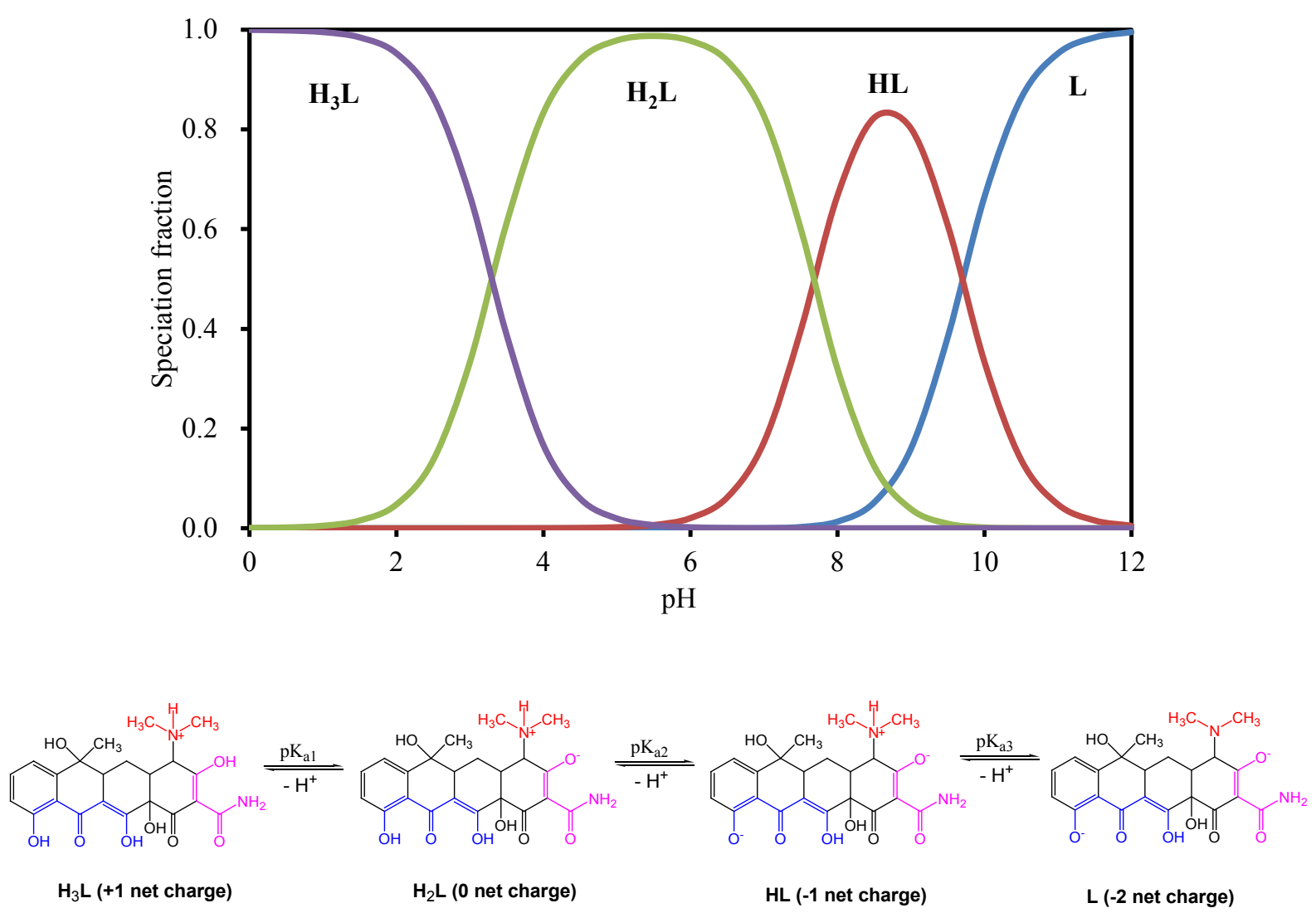

Figure S7. The speciation fraction of TC at different $\mathrm{pH}$. 

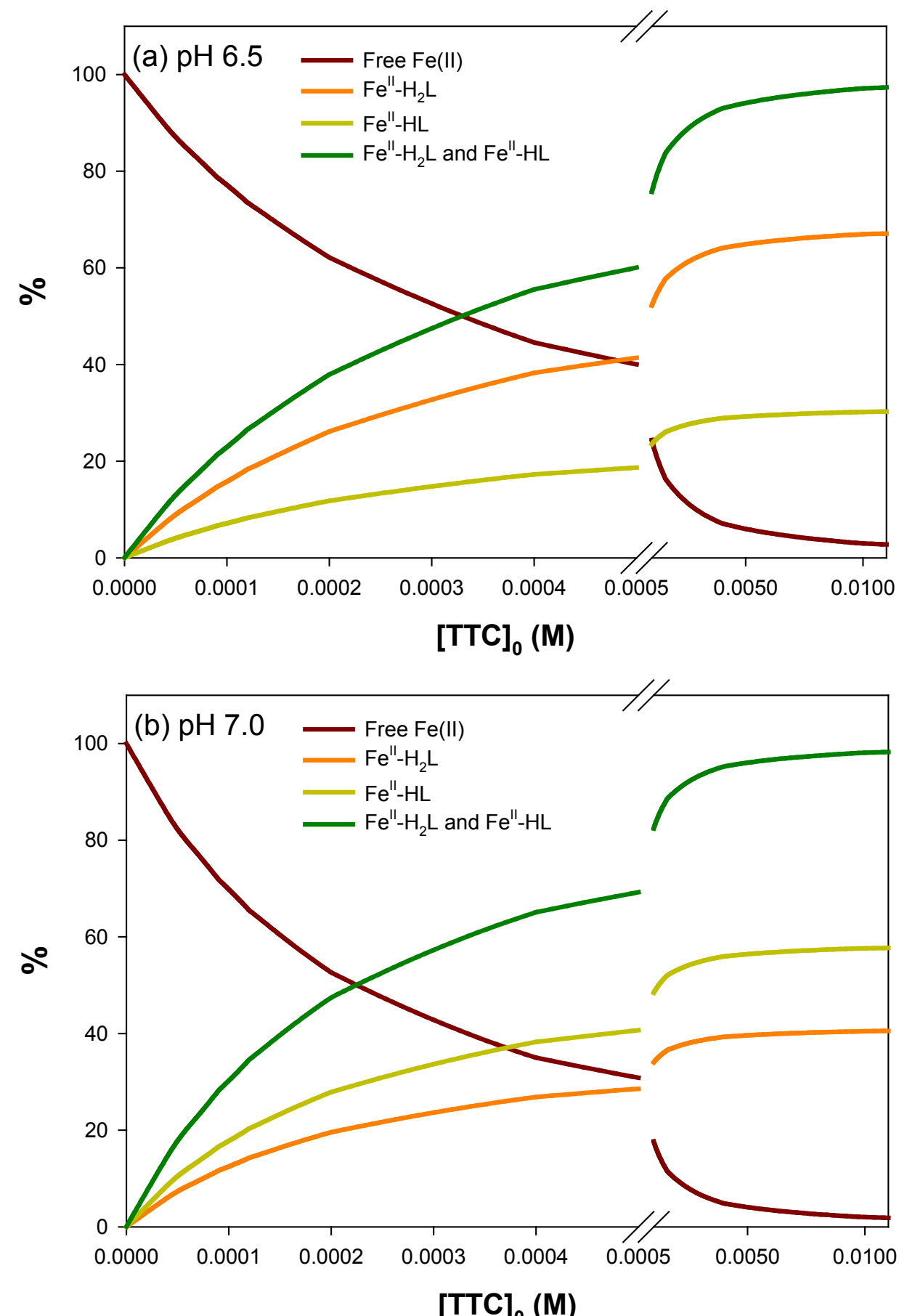

Figure S8. Fe(II)'s speciation in the presence of different amounts of TTC at pH 6.5 and 7.0. Condition: $[\mathrm{Fe}(\mathrm{II})]=40 \mu \mathrm{M}$. 


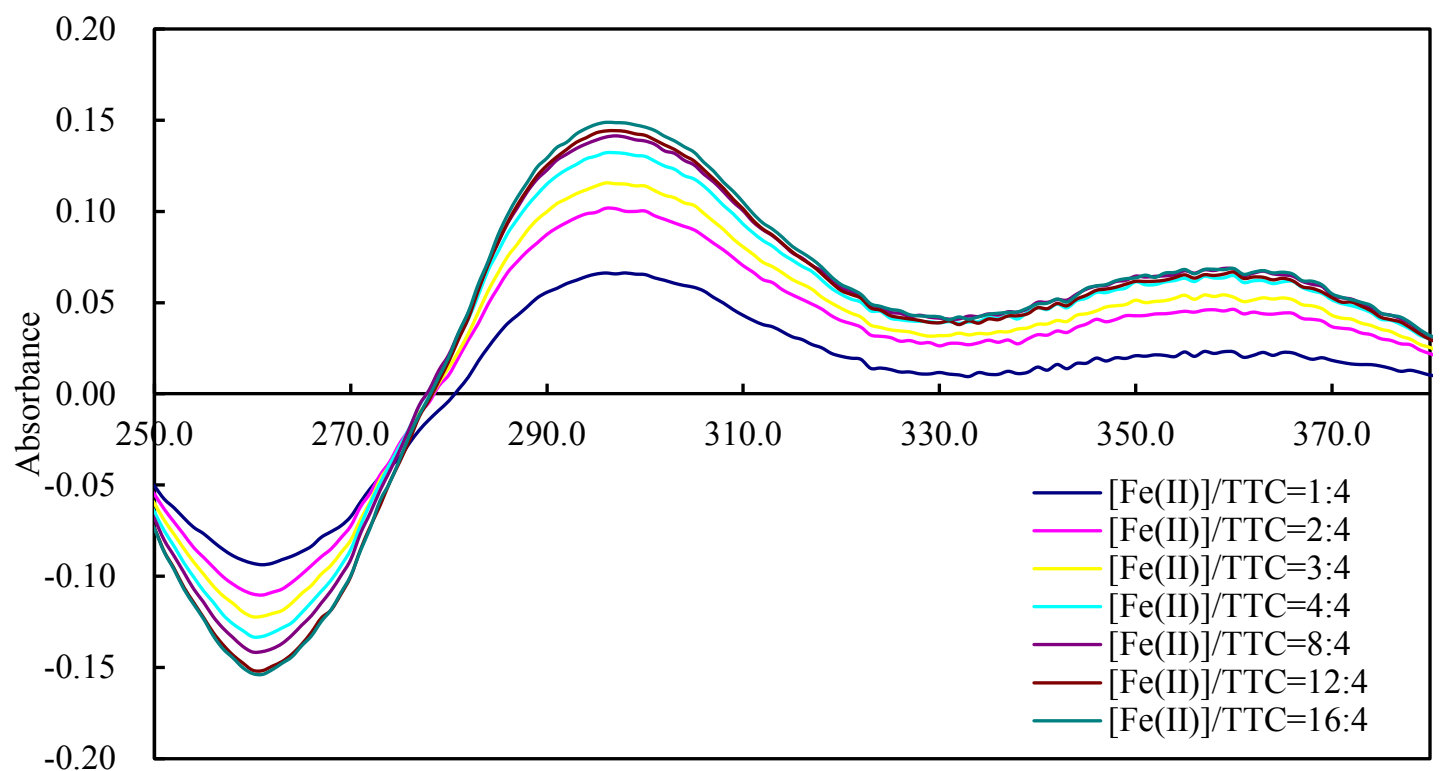

Wavelength (nm)

Figure S9. Changes in UV absorbance ( $\triangle$ Absorbance) under different $\mathrm{Fe}(\mathrm{II})$ :TTC ratios at wavelengths $250-380 \mathrm{~nm}$. Condition: [TTC] $=40 \mu \mathrm{M}, \mathrm{pH}=6.5$ (buffered by $10 \mathrm{mM}$ MOPS) 


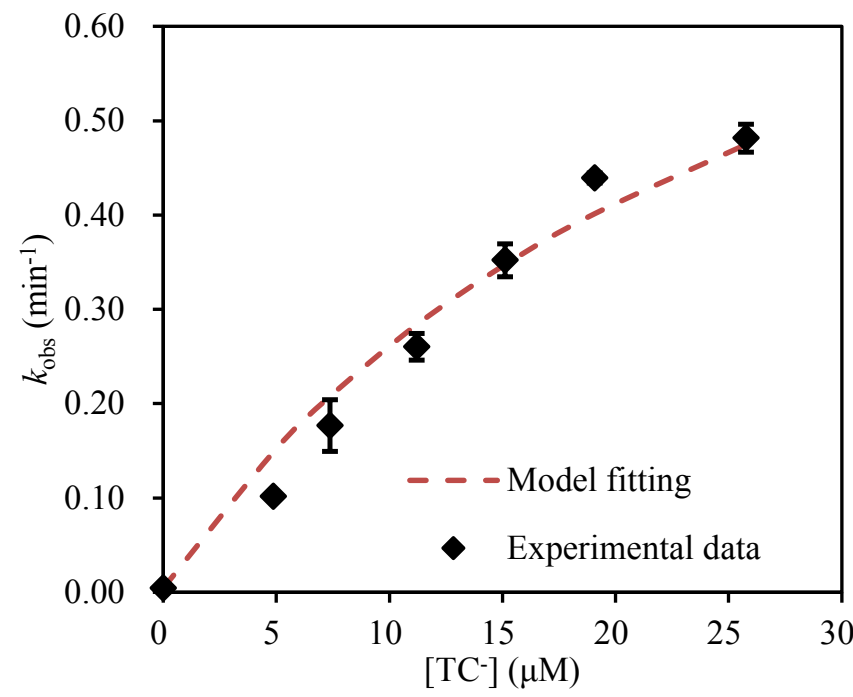

Figure S10. Experimental data and model fitting of observed Fe(II) oxidation rate constants with varying initial TTC concentrations at $\mathrm{pH}$ 7.0. Condition: $[\mathrm{Fe}(\mathrm{II})]_{0}=40 \mu \mathrm{M},[\mathrm{TTC}]_{0}=0$, 40, 60, 90, 120, 150 and $200 \mu \mathrm{M}$, buffered by $10 \mathrm{mM}$ MOPS, $\mathrm{T}=22^{\circ} \mathrm{C}$, with air purging. 

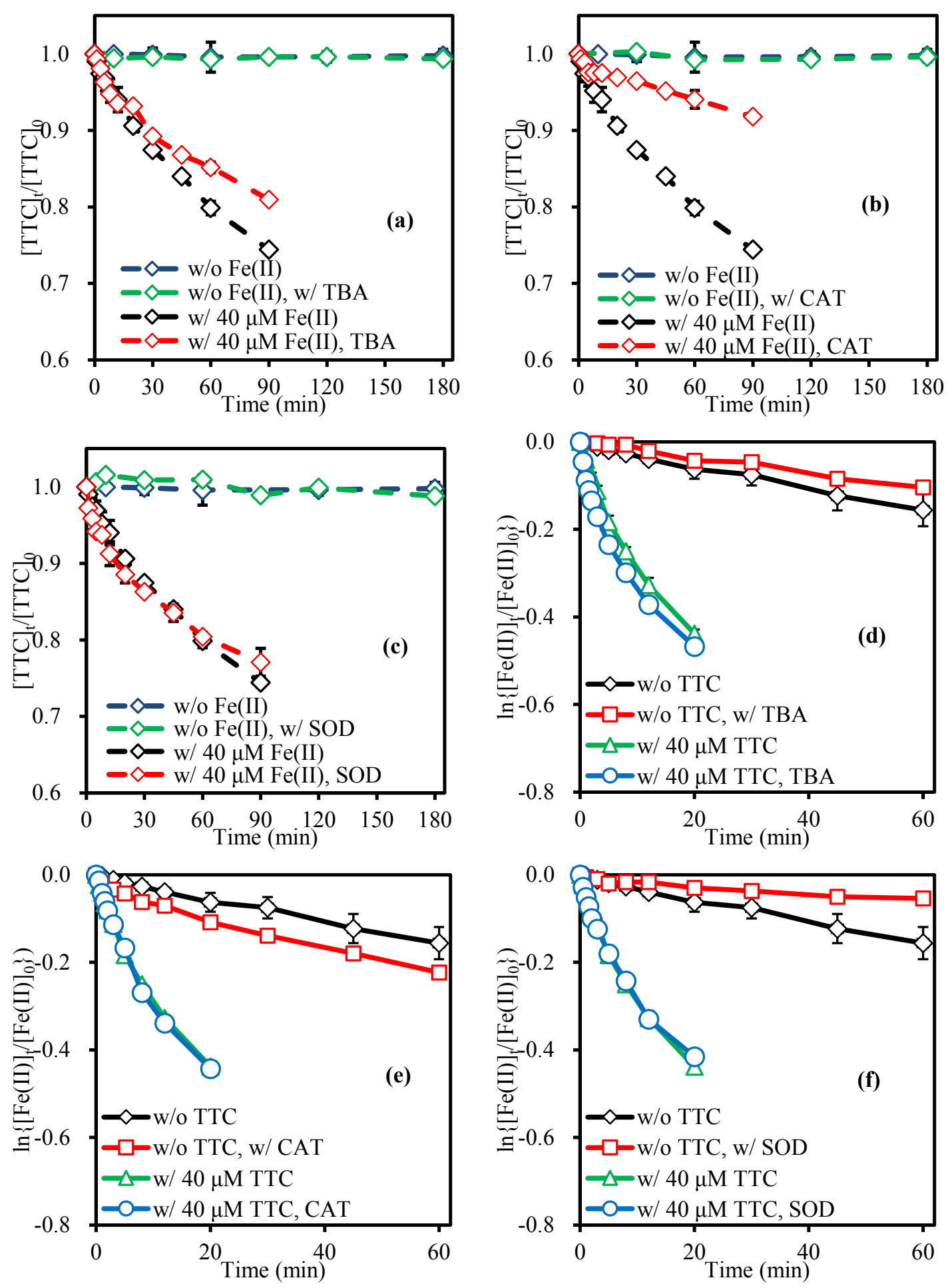

Figure S11. Effects of ROS scavengers (TBA, catalase, SOD) on TTC degradation and Fe(II) oxidation. Conditions: $[\mathrm{Fe}(\mathrm{II})]_{0}=[\mathrm{TTC}]_{0}=40 \mu \mathrm{M},[\mathrm{TBA}]=1.0 \mathrm{M}$, [catalase $]=400$ units- $\mathrm{mL}^{-1},[\mathrm{SOD}]=400$ units- $\mathrm{mL}^{-1}, \mathrm{pH}=6.5$ (buffered by $10 \mathrm{mM}$ MOPS), $\mathrm{T}=22^{\circ} \mathrm{C}$, with air purging. 

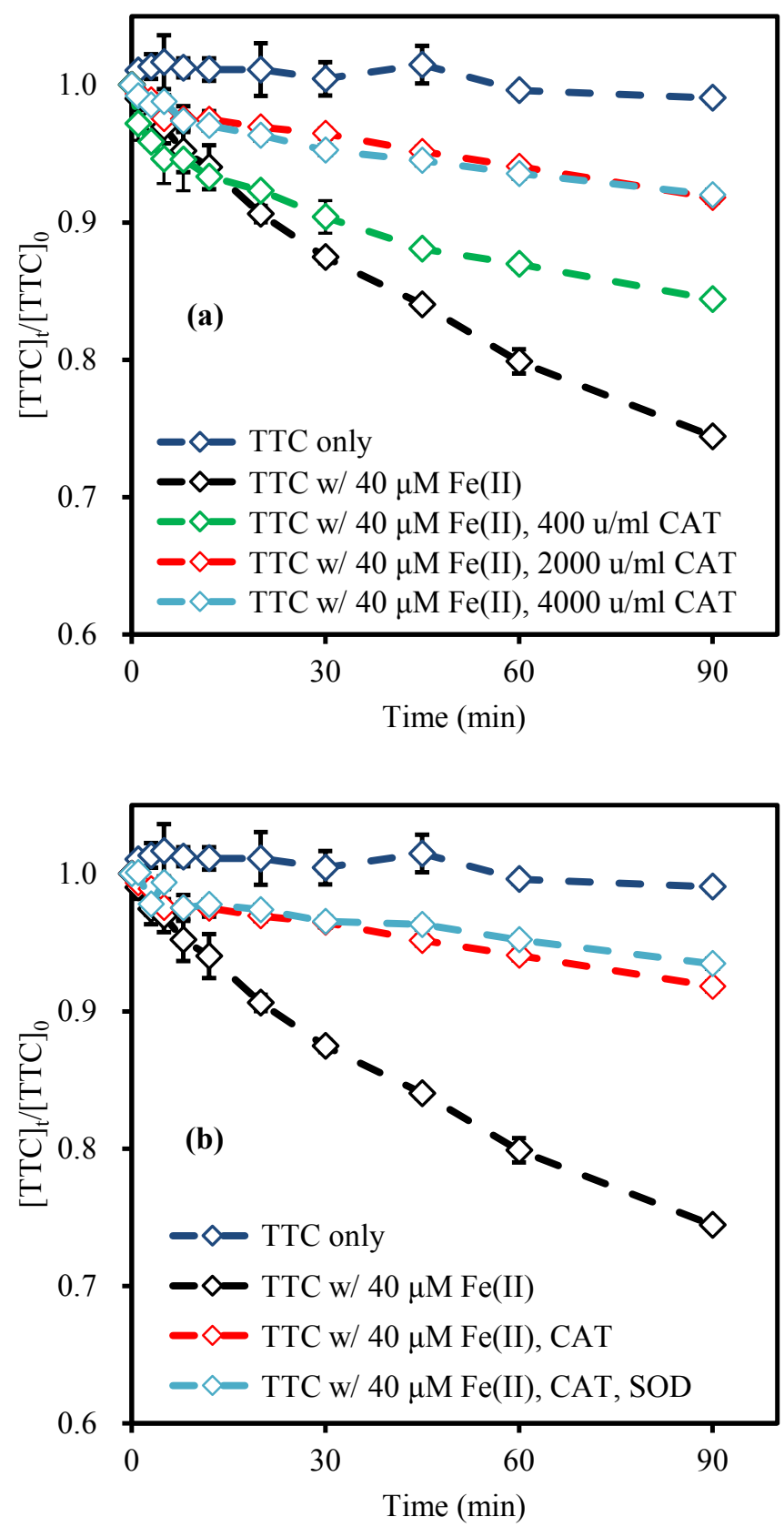

Figure S12. (a) Effect of catalase on TTC's degradation in the Fe(II)-TTC system. [catalase] $=400,2000,4000$ units $/ \mathrm{mL}$; (b) The influence of co-existence of catalase and SOD on TTC's degradation in the Fe(II)-TTC system, $[$ catalase $]=[\mathrm{SOD}]=400$ units $/ \mathrm{mL}$. Conditions: $[\mathrm{Fe}(\mathrm{II})]_{0}=[\mathrm{TTC}]_{0}=40 \mu \mathrm{M}, \mathrm{pH}=6.5$ (buffered by $10 \mathrm{mM}$ MOPS), $\mathrm{T}=22{ }^{\circ} \mathrm{C}$, with air purging 

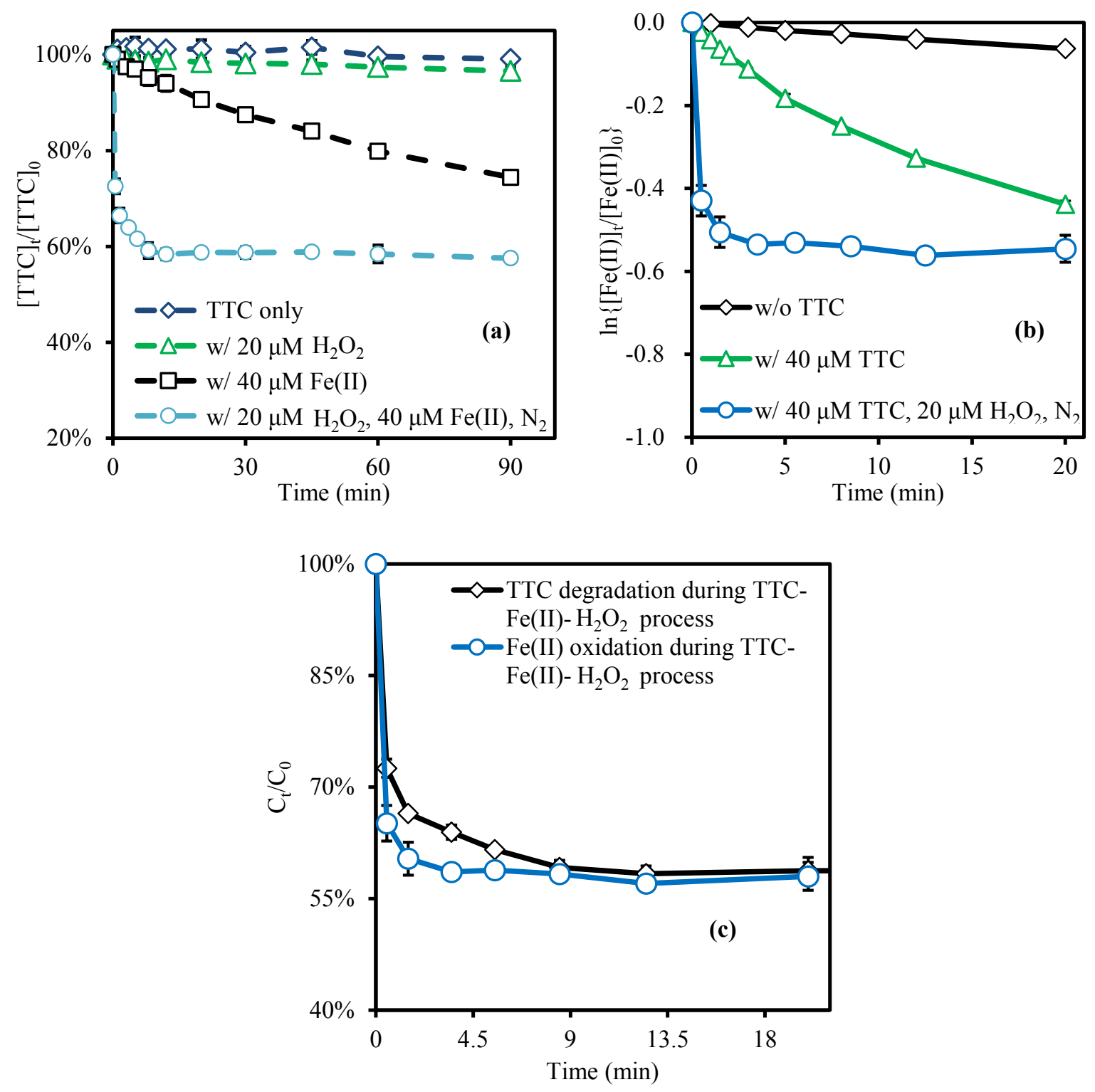

Figure S13. (a) Effect of $\mathrm{H}_{2} \mathrm{O}_{2}$ on TTC's degradation; (b) Effect of $\mathrm{H}_{2} \mathrm{O}_{2}$ on Fe(II)'s oxidation;

(c) The consumption of TTC and Fe(II) during the reaction. Condition: $[\mathrm{Fe}(\mathrm{II})]_{0}=[\mathrm{TC}]_{0}=40$ $\mu \mathrm{M},\left[\mathrm{H}_{2} \mathrm{O}_{2}\right]=20 \mu \mathrm{M}, \mathrm{pH}=6.5$ (buffered by $10 \mathrm{mM}$ MOPS), with nitrogen purging. 


\section{REFERENCES:}

(1) Rose, A. L.; Waite, T. D., Kinetic model for Fe(II) oxidation in seawater in the absence and presence of natural organic matter. Environ. Sci. Technol. 2002, 36, (3), 433-444.

(2) Huang, C. H.; Stone, A. T., Transformation of the plant growth regulator daminozide (Alar) and structurally related compounds with $\mathrm{Cu}^{\mathrm{II}}$ ions: Oxidation versus hydrolysis.

Environ. Sci. Technol. 2003, 37, (9), 1829-1837.

(3) Benesi, H. A.; Hildebrand, J. H., A spectrophotometric investigation of theinteraction of iodine with aromatic hydrocarbons. J. Am. Chem. Soc. 1949, 71, (8), 2703-2707.

(4) Stephens, C. R.; Murai, K.; Brunings, K. J.; Woodward, R. B., Acidity constants of the Tetracycline Antibiotics. J. Am. Chem. Soc. 1956, 78, (16), 4155-4158. 